\title{
Think Globally, Act Locally Environmental History as Global History in the First Global Age
}

\author{
Amélia POLÓNIA \\ Universidade do Porto \\ Porto, Portugal \\ amelia.polonia@gmail.com
}

\section{Abstract}

The paper is oriented towards a reflection on the epistemological extension of world history. This discipline is currently opening up for new subjects and new foci of interest, with environmental history being one of them. The paper debates the interaction between the global and the local as one of the main issues of world history. It analyses the impacts of the interconnectivity of diverse regions as well as different geographical and cultural complexes, during the period between 1500 and 1800.

Assuming that the sea in its economic, cultural and environmental dimensions contributed actively to world history, and is, in itself, a major factor of globalization, the paper intends to highlight interdependencies which fostered connections between the local and the global. It further submits to discussion which was the impact of an on-going globalization process, based on maritime dynamics, on the environment. Through an analysis centered on the impact of European overseas expansion, some environmental impacts will be analyzed.

The paper aims at questioning environmental history as an emergent theme of world history, based on the historical experi- 
ence of connecting worlds developed in the First Global Age (150o1800).

\section{Key words}

environmental history, colonial history, trans-imperial history, world history, global history, connected history

I. ENVIRONMENTAL HISTORY: DisCIPLINARY GROUND FOR WORLD AND GLOBAL HISTORY

Both "World History" and "Global History" seek the affirmation of different epistemological grounds, confirmed by the existence of different associations, different affiliations and different scientific journals. Researchers are called to take positions in those debates and to affiliate themselves to one of the historiographical "schools."

The rise of a new discipline usually implies the definition of a concrete object of study, a distinct theoretical framework and a specific methodology, as, e.g., in Economic History, Cultural History, or Environmental History. The same, however, cannot be said for either World History or Global History. They do not have a circumscribed scientific domain, nor are they defined by a particular methodology or conceptual framework. Instead, their claim to legitimacy as historiographical categories is based on the assumption that the scale (the global, the world-wide) and the dynamics presumed by that scale justify their standing as specific areas of historical knowledge. ${ }^{1}$

World History is assumed to be devoted to the historical analysis of a range of comparative and cross-cultural studies on forces that worked their influence across cultures and civilizations, world historians claiming a global and comparative perspective of analysis as the very essence of their work. ${ }^{2}$ They call for an unambiguous positioning, quite different from the one as-

${ }^{1}$ Matthias Middell and Katja Naumann, "Global History and the Spatial Turn: from the Impact of Area Studies to the Study of Critical Junctures of Globalization,” Journal of Global History 5, no. 1 (March 2010): 161.

${ }^{2}$ http://www.uhpress.hawaii.edu/t-journal-of-world-history.aspx. 
sumed by Global History. As for Global History, the Oxford Global History Research Centre claims as its main fields of research the global movement of people, goods and ideas and the consequences that flow from them. They claim to promote the study of themes of global significance, including, among others, the dialogue between imperial, transnational and comparative history, the balance in the dialogue between cultures in different historical periods, including the practices of translation and their cultural significance. The development of economic interdependency, in relation to technological transfer and scientific interchange, and the movement of peoples as against the movement of ideas and practices are other preferential topics of Global History. ${ }^{3}$ Connections with climatology or the history of the environment are lately assumed as fitting its field of research as well.

As for its counterpart, World History, it is conceivably more widely represented all over the world, and less centered on the research promoted by the Anglo-Saxon academic sphere. Claiming to circumvent and overcome the allegedly Eurocentric perspectives and historiographical understandings, ${ }^{4}$ it presents itself as an equally adequate ground for exploitations of environmental history.

The frontiers between both disciplinary areas remain, nonetheless, unclear and tenuous. Both see the need for multiand trans-disciplinary studies, and both try to answer historiographical questions that cannot be answered at a national or regional level. Both focus on dynamics which require an understanding of worldwide assessments and are based on the functioning of a geographical, political, economic and cultural interconnectivity that goes beyond geographical or political frontiers. ${ }^{5}$ Environmental phenomena are, no doubt, among those

\footnotetext{
${ }^{3}$ http://global.history.ox.ac.uk/

${ }^{4}$ Bruce Mazlish, "Comparing Global History to World History," Journal of Interdisciplinary History 28, no. 3 (Winter 1998): 385-95.

${ }^{5}$ Among the many publications, see in particular, Bruce Mazlish and Ralph Buultjens eds., Conceptualizing Global History (Boulder: Westview Press, 1993); Bruce Mazlish, “Comparing Global History to World History,” Journal of Interdisciplinary History 28, no. 3 (Winter 1998): 385-439; A. G. Hopkins, "The History of Globalization and the Globalization of History?” in Globalization in World History, ed. Hopkins (London: Norton, 2002), 11-46;
} 
topics, and environmental history claims to be inextricably interconnected with Global History. Or shall we say World History?

In this paper we will focus our reflection on a very circumscribed set of questions arising within the context of a globalization process, connected with European maritime expansion and colonization in the Early Modern Age. Its focus is twofold: on the one hand, it intends to discuss the connections between the local and the global; on the other hand, it aims to analyze how colonialism and environmental issues connect and intermingle.

\section{THE INDIAN OCEAN: EXPLOITATION GROUND FOR ENVIRONMEN- TAL HISTORY}

Within the history of globalization and, thus, on the overall dynamics comprehending the "First Global Age" (from 1500 to 1800 according to a European point of view), oceans perform as the main channels for global transfers. ${ }^{6}$

Hopkins, introduction to Global History: Interactions between the Universal and the Local, ed. Hopkins (Basingstoke: Palgrave Macmillan, 2006), 1-38.

${ }^{6}$ The author is aware of the debate that suggests the pre-existence of a global circulation of men, goods, and ideas in the Indian Ocean before the arrival of the European, namely the Portuguese. See among others, Andre Gunder Frank, ReORIENT: Global Economy in the Asian Age (Berkeley: University of California Press, 1998); Donald F. Lach, Asia in the Making of Europe, 3 vols. (Chicago: University of Chicago Press, 1965-1993), or Anthony Reid, Southeast Asia in the Age of Commerce, 1450-1680, 2 vols. (New Haven: Yale University Press, 1988-1993). The concept of First Global Age is here applied for a period of time in which planetary connections were established on a regular and permanent basis linking all the continents and oceans. Even if this concept is usually applied to the period between 14001800 (considering the beginning of the Portuguese expansion in 1415, with the military conquest of Ceuta), this paper identifies it as beginning in 1500 (after the maritime connection established between the Atlantic and the Indian Oceans by Bartolomeu Dias, in 1488, and the arrival of Vasco da Gama in Calicut, in 1498). This proposal assumes that only regular global maritime runs permit global connections between all the geographical, economic and cultural universes around the world. It further assumes that the building up of this First Global Age extrapolates the colonial processes and requires, not only trans-national and trans-imperial connections, but the existence of formal and informal networks of cooperation between all the agents and entities involved, European and non-European alike. See, among others, J. R. McNeill and William H. McNeill, The Human Web: A Bird's-Eye View of World History (New York: W.W. Norton, 2003). For a better understanding of the concept see Amélia Polónia, "Informal self-organised networks in the First Global Age. The Jesuits in Japan," Bulletin of the Institute for World Affairs and Cultures, Kyoto Sangyo University 28 (February 2013): 133-58. 
"Seen as highways of trade, routes of migration, paths for communication flows, spawning grounds of political and economic empires, offspring of miscegenation processes between different civilizations and cultures . . . the seas, oceans and their dynamics emerge as a crucial field of study directly connected with global history. Since the oceans are usually seen as levers for globalization processes and as key factors in the creation of the "First Global Age," maritime history becomes indeed a "gateway to global history." While this applies to any ocean it is particularly true when applied to the Atlantic during the era under consideration, or to the Indian Ocean even much earlier.

Comparing the Indian Ocean with others sea and oceans, Michael Pearson is clear about both the difference of the scale and the time span during which the Indian Ocean can be perceived as a ground for global dynamics. The same is stated by many others Indian Ocean historians, from which Janet AbuLughod work stands. ${ }^{8}$ We argue that this point applies to maritime studies as well as to economic and political or to cultural and environmental studies.

Pearson's appraisals remain central to the study of the Indian ocean. The author notes that this ocean is by far the oldest of the seas in history, in terms of it being used and traversed by humans. The first sea passage in human history was over its waters, regular connections between two early civilizations dating back over 5,000 years." As for its surface, Pearson argues that the Baltic covers 414,00o $\mathrm{km}^{2}$, the North Sea 520,000, and the Mediterranean, 2,516,00o. The Indian Ocean on the largest definitions, going down to Antarctica, covers no less than $68,536,000 \mathrm{~km}^{2}$."10

This is not, however, only a question of dimension or precedence of its uses as a highway for trade. It is its history and prehistory which position it as a main stage for long-term studies on environmental history connected or not with colonial history.

${ }^{7}$ Amélia Polónia, "Maritime History: A Gateway to Global History?” in Maritime History as Global History, ed. Maria Fusaro and Amélia Polónia (St. Johns, Newfoundland: IMEHA, 2010), 14-15.

${ }^{8}$ Janet L. Abu-Lughod, Before European Hegemony: The World System A.D. 12501350 (New York: Oxford University Press, 1991).

${ }^{9}$ Michael Pearson, The Indian Ocean (New York: Routledge, 2003), 3.

${ }^{10}$ Ibid., 4. 
An abundant literature points to the fundamentally different history of the Indian Ocean when compared with others, as well as to its long history of contact and distant voyages done by people from its coasts. In this long-term set-up there seems to be a brief hiatus, maybe 150 years, when westerners controlled things. ${ }^{11}$

In a historiographical setting in which the environmental history of this period is mostly analyzed as the linear result of a European colonial set-up, the Indian Ocean emerges thus as a detached ground for debate and comparative studies-before, during and after the European dominance. Assuming that environmental dynamics result from natural and ecological settings as much as from economic, political and cultural variables, this is a privileged stage for debates carried on within the scope of this still recent discipline.

The study of the oceans does not involve, strictly speaking, only maritime studies, nor does it comply with the approaches of any single discipline. Matt K. Matsuda claims that studying and even defining an ocean historically requires the assimilation of multiple disciplines and scholarly domains. ${ }^{12}$ He argues persuasively that comprehending the Pacific as an entity requires the inclusion of anthropological studies of islanders, approaches to the Pacific rim, policy issues and economic development, along with navigational, immigration and diaspora studies on Oceania, East and Southeast Asia and the Americas. He concludes that contributions by ethno-botanists, musicologists, historical linguists, marine archaeologists, poets, novelists and political activists are necessary for such an endeavor. The same point is argued by Paul d'Arcy in his The people of the Sea, ${ }^{13}$ following the path of K. R. Howe ${ }^{14}$ according to whom the history of the Pacific depends on the understanding of the human-environment relation

${ }^{11}$ Among others, Pearson, The Indian Ocean and K. N. Chauduri, Trade and Civilisation in the Indian Ocean: An Economic History from the Rise of Islam to 1750 (Camgridge: Cambridge University Press, 1985).

${ }^{12}$ Matt K. Matsuda, “AHR Forum: The Pacific,” American Historical Review 111, no. 3 (June 2006): 758-80.

${ }^{13}$ Paul D'Arcy, The People of the Sea: Environment, Identity, and History in Oceania (Honolulu: University of Hawai'i Press, 2008).

${ }^{14}$ K. R. Howe, Nature, Culture and History: The "Knowing” of Oceania (Honolulu: University of Hawai'i Press, 2000). See as well Jerry H. Bentley, Renate Bridenthal, and Karen Kären Wigen, eds., Seascapes: Maritime Histories, Littoral Cultures, and Transoceanic Exchanges (Honolulu: University of Hawai’i Press, 2007). 
as much as on the land and sea articulation. The sea shaped the people of Oceania: it became more important than land to an understanding of the human societies of the Pacific, since its influence is extensive and its dynamics are active and influential. Those are central findings to which environmental studies can contribute and from which it can benefit on its path towards a more articulated understanding of ecological dynamics.

The same has been argued about the Indian Ocean. Michael Pearson, too, called for a challenge to maritime studies of the Indian world: "We must try to identify people whose social life is importantly tied in to the ocean, that is people of the sea." 15 The discussion of how far inland an historian of the oceans (or of the maritime environments) must go in order to identify maritime projections and dynamics, ${ }^{16}$ is thus also informed by this overall connection between land and sea, which is implied in the overall history of the Indian Ocean, including its environmental history.

\section{III. “THINK GLOBALLY, ACT LOCALLY”: WHEN THE LOCAL BECOMES GLOBAL}

Even if environmental phenomena frequently earn a worldwide dimension and gain from a global analysis, since nature has no frontiers, there is nevertheless some criticism towards the viability of a global environmental history. Douglas Weiner, following Richard White, ${ }^{17}$ argues that "we can make believable statements about some effects by local actors on environments of local scale, but beyond that we get into chaos theory." 18 And even those who pursue a path of Global History, like Joachim Radkau, show identical skepticism concerning history as global: "By widening history towards a global horizon, the empirical basis becomes

${ }^{15}$ Pearson, The Indian Ocean, 27.

${ }^{16}$ Ibid.

${ }^{17}$ Richard White, “The Nationalization of Nature," Journal of American History 86, no. 3 (December 1999): 976-86.

${ }^{18}$ Douglas R. Wiener, “A Death-Defying Attempt to Articulate a Coherent Definition of Environmental History,” Environmental History 10, no. 3 (July 2005): 405. 
glib; the global approach usually raises the danger of speculative constructions and fashionable dilettantism." ${ }^{19}$

In fact, even if neither Global History nor World History are the absolute sum of local histories, the whole being greater than the sum of its parts, they cannot exist without interconnecting different spaces of observation, within a local, regional and inter-regional scale. Accepting this rationale implies, as consequence, that no historical phenomenon, even if on a worldwide and global scale, can be understood without observations on a local or regional scale in terms of empirical analysis. It is also at a local scale that the effects of global phenomena are identified and can be studied. It does not mean or imply the call for any kind of "national," even less a "nationalist" construction of environmental history-nation or state are in fact categories that apply neither to Early Modern Age, a period for which the concept itself of nation-state is anachronistic, nor to environmental studies. $^{20}$

Furthermore, evaluating, on a stable basis, long-term changes and environmental processes for the pre-statistical era, seems frequently an impossible task. That is also why local inquiries and micro-analyses facilitate analyses in a context in which macro-level approaches cannot be pursued.

This rationale has another implication, related to effective interventions in environmental dynamics. If you want to change global tendencies you have to act on a local basis and involve local communities within their daily schedule. The slogan "Think globally, act locally," expresses this exact concern: you might think globally, but as for your action, local is the available scale of intervention. ${ }^{21}$

This is why the local becomes global, both as a reception ground where global phenomena impact, and as the arena for an

${ }^{19}$ Joachim Radkau, "World History and Environmental History," in Encyclopedia of Life Support Systems (EOLSS). Developed under the Auspices of the UNESCO (Oxford, UK: Eolss Publishers, 2008) [http://www.eolss.net]

${ }^{20}$ White, “The Nationalization of Nature," 976-86.

${ }^{21}$ Even David Armitage, who helped define some of the major trends in Atlantic History, Digital Humanities and Big History, calls for a micro-macro interplay as a fundamental dialectic to provide meaning to historical analysis. Jo Guldi and David Armitage, The History Manifesto (Cambridge: Cambridge University Press, 2014). 
active public intervention in order to enable transformative plans to overcome phenomena highly harmful for mankind.

Changes deriving from human behavior have thus to be understood and stimulated at a local base as much as they must involve international and worldwide interconnected policies. Cultural settings are also determining factors when trying to understand attitudes with far-ranging projections on the environment, as it happens, e.g., with policies and attitudes toward whaling in the Eastern and Western worlds.

Those are some of the theoretical premises of this essay, in its attempt to question the environmental impact which resulted from the new historical uses of the oceans, by the Europeans between 1500 and 1800 , the period here identified as "The First Global Age." It also applies to the scrutiny of the results of the interaction of human action in environmental ecosystems caused by European overseas expansionism and the ensuing worldwide colonial process.

\section{MAKING CONNECTIONS: ENVIRONMENTAL IMPACTS OF THE CO- LONIAL PROCESS IN THE FIRST GLOBAL AGE ${ }^{22}$}

Worldwide dynamics of exchange, resulting from the interconnectivity between oceans, provided by regular maritime runs, had been established by the 15th century onwards, with significant impact on continental spaces. We argue that there is an unavoidable connection between the Europeans' use of the oceans and the global environmental impacts shaped by the European colonial settlements. The 16th century is generally seen as a time of growing interconnectivity between several continents and oceans. The use of the seas as highways of communication, rather than as insurmountable barriers was one of the preconditions for those achievements. This led to the creation of a world economy, as well as to environmental impacts as the result

${ }^{22}$ See, on this subject, Amélia Polónia, "The Environmental Impacts of the Historical Uses of the Seas in the First Global Age (1400-1800),” in Encyclopedia of Life Support Systems (EOLSS). Developed under the Auspices of the UNESCO (Oxford, UK: Eolss Publishers, 2014) [http://www.eolss.net]. 
of a global process of transfers, responsible for emerging syncretic biomes. ${ }^{23}$

The role of overseas navigation, maritime circuits and overseas trade is, thus, a key element to be considered in order to understand the genesis of a global economy and the transfers of both natural resources and raw materials at a global level. The oceans provided the means and the channels for these massive cross-cultural and material exchanges, on an unknown scale, covering distances never travelled before.

The factors of time and distance acquired new values in the equation of maritime transport costs. At the same time technological developments in shipbuilding, and new scientific achievements in nautical science contributed greatly to the increase of long-distance maritime navigation. Only those requirements provided the necessary conditions to permit worldwide transportation of people, information, goods, commodities and plants at a level unknown until the First Age of Globalization.

Europeans invaded the Old and New Worlds, aiming for a quick, effective and profitable use of their resources. Overseas settlements and long-distance trade were established, and economic emporia and political empires were created, changing the world system for good and causing long term environmental impact upon the New Worlds, in a process which became generally acknowledged as "ecological imperialism." 4

Our subject is not new in historical research. Alfred Crosby, an environmental historian, set the tone for a field of research which strongly appealed to a significant number of disciples. His focus is mostly centered on so-far largely ignored factors of imperialism. In his work, environmental colonialism became the ultimate expression of European imperialism. Current expressions of this historiographical trend are conveyed in a long list of works authored by his followers, among whom stand out Richard Grove's Green Imperialism, ${ }^{25}$ or John F. Richards' book The

${ }^{23}$ Alfred W. Crosby, Ecological Imperialism: The Biological Expansion of Europe, 900-1900, 2nd ed. (Cambridge: Cambridge University Press, 2004).

${ }^{24}$ Ibid.

${ }^{25}$ Richard Grove, Green Imperialism: Colonial Expansion, Tropical Island Edens, and the Origins of Environmentalism, 1600-1860 (Cambridge: Cambridge University Press, 
Unending Frontier: An Environmental History of the Early Modern World. ${ }^{26}$ Following the perspective of Alfred Crosby, common problems of depletion, exhaustion of resources, frontier land conflicts, damage of ecosystems and indigenous cultures are presented as the result of state or imperial-oriented policies. $^{27}$

Environmental colonialism seems, in this context, much more important than any other kind. And, in fact, a colonial economy, ruled by European markets, introduced new patterns of territory management, property regimes ${ }^{28}$ and soil exploitation. In America, colonial plantations, based on monoculture and latifundia, tended to dominate. Along with cattle breeding, they unbalanced old equilibriums and the profile of autochthone economies. ${ }^{29}$ Sugar, coffee, cacao, tobacco, tea, and rice were transplanted to regions where they had never existed before, replacing old plantations or totally invading unexploited lands. Their cultivation consumed fertile soils, together with timber and tropical forests, required by a quest for arable land and for the energy necessary at the service of sugar mills.

Native societies and communities, along with their cultures and economies (agrarian or not) were first pushed back, then partially or totally shattered by the new plantations' regime, the new patterns of land exploitation and the new norms of land property, imposed by force or by deception. As the concept of property itself was unknown to most of the American and some

1996); and Grove, Ecology, Climate, and Empire: Colonialism and Global Environmental History, 1400-1940 (Cambridge: White Horse Press, 1997).

${ }^{26}$ John F. Richards, The Unending Frontier: An Environmental History of the Early Modern World (Berkeley: University of California Press, 2003).

${ }^{27}$ Grove and Richards go, nevertheless, further and deeper in their analysis of the colonial impacts on environmental phenomena, proposing a more complex understanding of the web of factors intervening in the process: demographic pressure, technological evolution, need for increased sources of energy are largely put forward as levers of environmental changes, at the same time the view of an "imperialistic determinism" is more critically scrutinized.

${ }^{28}$ Hans J. Prem, "Spanish Colonization and Indian Property in Central Mexico, 15211620,” Annals of the Association of American Geographers 82, no.3 (September 1992): 44459.

${ }^{29}$ Rollie E. Poppino, “Cattle Industry in Colonial Brazil,” Mid-America 31, no. 4 (October 1949): 219-47; Stuart B. Schwartz, "Colonial Brazil, c. 1580 - c. 1750: Plantations and Peripheries” in The Cambridge History of Latin America, ed. Leslie Bethell (Cambridge: Cambridge University Press, 1984). 
African indigenous people, their own property rights went unrecognized by most colonizers or were circumvented with misleading strategies, legal or not. The uses of land and environmental management became driven by new requirements and rationalities, and by new agents and demands-foreigners to the local and regional settings affected by these dynamics.

The same process affected first the West Indies, ${ }^{30}$ then Spanish America, and subsequently, the areas from México and Peru to the California region. Mining, first, and then extensive colonial plantations of tobacco, cotton and sugar, invaded the Antilles and extensively contributed to the annihilation of local tribes and their environment and economies: the Tainos, the most numerous indigenous group, were nearly extinguished. Famine, cultural depression and infectious diseases, mostly influenza, resulted in high mortality rates. During the short period between 1492 and 1542, the Tainos of Hispaniola became nearly extinct. ${ }^{31}$ In some of the Antilles, what mining and colonial plantations did not accomplish in terms of environmental impact and ecosystems, cattle breading and ranching did..$^{32}$

In the Spanish Americas' mainland, gold and silver exploitation, extensive livestock, epidemic outbursts, side by side with the impact of indented or enslaved labor, through the Encomiend $a^{33}$ and the Repartimiento system ${ }^{34}$ provoked both the de-

${ }^{30}$ The West Indies include the Greater Antilles (Cuba, Puerto Rico, Hispaniola, Jamaica, the Bahamas), and the Lesser Antilles (Barbados, Nevis, Antigua, Anguilla, Barbuda, Montserrat, among others islands).

${ }^{31}$ Cf. Francisco Guerra, “The European-American Exchange," History and Philosophy of Life Science 15, no. 3 (1993): 313-27; "The Earliest American Epidemic: the Influenza of 1493," Social and Science Review 12, no. 3 (1988): 305-25; Alfred Crosby, "Conquistadory Pestilencia: The First New World Pandemic and the Fall of the Great Indian Empires," Hispanic American Historical Review 47, no. 3 (1967): 321-37; Richards, The Unending Frontier, 315- 33.

${ }^{32}$ Terry J. Gordon, "Implantments and Adaptations in the West Indies," in NorthAmerican Cattle Ranching Frontiers: Origins, Diffusion and Differentiation (Albuquerque: University of New Mexico Press, 1993), 65-121.

${ }^{33}$ The encomienda was the system employed mainly by the Spanish crown during the first period of the colonization of the Americas to regulate Native American labour. The Spanish crown granted a person a specified number of natives for whom they were to take responsibility. It became, in practice, a kind of slavery, even if not legally.

${ }^{34}$ The repartimiento was a forced labour system imposed upon the indigenous population of Spanish America, as well as the Philippines, later on. It was a tribute-labour system, affiliated in the mita of the Inca Empire or the corvée of Ancien Régime France: the natives were forced to do low-paid or unpaid labour for a certain number of weeks or months each year on Spanish-owned farms, mines, obrajes, and public projects. This system intended to 
pletion of ecosystems and a human exhaustion as high as 90 percent in some Mexican regions. ${ }^{35}$ Increasingly, formerly unexploited lands were taken by Spanish settlement and ranching, changing the natural and environmental equilibriums. ${ }^{36}$ Mining activities in the Spanish Americas emerge as similarly responsible for the exhaustion of resources ${ }^{37}$ and, more than that, for an extended pollution increased by the use of mercury in its transformation process. ${ }^{38}$

Portuguese settlement in Brazil followed similar patterns even if with less extensive and immediate effects. Apart from the shoreline and the more intensive exploitation of the coastal fringes of Portuguese capitanias, ${ }^{39}$ there were the substantive activities of the bandeirantes, informal expeditions searching for precious metals and capturing indigenous people, acting without frontiers all over South America. More than anything, it was the gold and diamond exploitation period, from the end of the 17th century onwards, that became responsible for a more extended and aggressive predation of Brazilian territory and ecosystems.

The assimilation of Indians in Brazil matched the changes in their ecosystems. The massive forced migration of African populations was not without cultural and natural consequences to the American worlds.

In the East and Far East, Europeans were one group among many others who had settled in the region for centuries, imposing different empires, political rules, or just adapting to a trade

replace the Encomienda system, and was tried to be implemented by the 1542 New Laws (Leis Novas), formulated by the Spanish Crown, to which colonist were extremely resilient. Both encomineda and repartimiento implied moving indigenous population from their own villages and communities.

${ }^{35}$ Daniel T. Reff, Disease, Depopulation and Culture Change in Northwestern New Spain. 1518-1764 (Salt Lake City: University of Utah Press, 1991); Nicholas SánchezAlbornoz, "La Pobación de la America Colonial Española,” in América Latina en la Epoca Colonial, ed. Miguel Léon Portilla et al. (Barcelona: Editorial Critica, 1990), 2:9-32.

${ }^{36}$ Richards, The Unending Frontier, 334-79.

${ }^{37}$ Philip Wayne Powell, Soldiers, Indians, and Silver: The Northward Advance of New Spain, 1550-1600 (Berkeley; Los Angeles: University of California Press, 1952).

${ }^{38}$ A. Martinez-Cortizas et al., "Mercury in a Spanish Peat Bog: Archive of Climate Change and Atmospheric Metal Deposition,” Science 284, no. 5416 (May 1999); Peter Bakewell, "La minería en la Hispanoamérica Colonial,” in América Latina en la Epoca Colonial, ed. Miguel Léon Portilla et al. (Barcelona: Editorial Crítica, 1990), 2:131-53.

${ }^{39}$ Capitanias are administrative divisions of some Portuguese colonies, including 
regime in which the plurality of partners was the norm. All of them had to deal with an ever-changing environment. Nevertheless, the European footprint was substantial, e.g. by the transportation of new seeds and germs from other worlds such as the introduction of plantations of other species within the Indian oceanic world. That is the case with some kinds of South-East Asian spices the Portuguese introduced to the Indian sub-continent, more specifically in the Goa region and on the Malabar Coast. The British imperial impact in India seems to have been more extensive still. Under British imperial rule, India's forests were depleted not only by the expansion of cultivated land, but also by both commercial timber operations and plantation cropping for European markets. ${ }^{40}$ The same could be said about the impact of Spanish colonialism, in particular in the Philippines, as shown in the works of Greg Bankoff. ${ }^{41}$

Previous to 1800, a comparable impact of European systems of exploitation is acknowledged for South Africa, induced by the Dutch, and in Australia, led by the British. In the Cape region, the southern pillar of Africa, opportunistic plantations, first aiming to provide European crews with food, wine and supplies in order to guarantee trans-oceanic navigations, then directed to exportation, transformed an ecosystem hardly touched before the Dutch colonial presence (1652) into a Europeanized agrarian landscape. As stressed by Richards, by the end of the Dutch period (1795), nearly all the larger fauna of the entire Cape region had been depleted by inexorable hunting, even more lethal once the new settlers used firearms. Elephants, rhinoceroses, hippopotamuses, and other large, vulnerable animals had long since disappeared. As the frontier expanded, wildlife diminished. ${ }^{42}$

At the same time seas were changing in a direct relation with European colonialism, some species of fish and animals were threatened by large-scale catches. Those were imposed by

${ }^{40}$ Richard P. Tucker, "The Depletion of India’s Forests under British Imperialism: Planters, Foresters, and Peasants in Assam and Kerala," in The Ends of the Earth: Perspectives on Modern Environmental History [Studies in Environment and History], ed. Donald Worster (Cambridge: Cambridge University Press, 1988), 118-40.

${ }^{41}$ Greg Bankoff, "One Island Too Many: Reappraising the Extent of Deforestation in the Philippines Prior to 1946,” Journal of Historical Geography 33, no. 2 (April 2007): 31434.

${ }^{42}$ Richards, The Unending Frontier, 306. 
the demands of distant consumption markets, ruled by European logics and needs, and commanded by European merchant rationalities. Codfish, tuna, and whales are just some of the species targeted by this aggressive predation.

Portuguese, Breton, Norman, Spanish and French Basque fishermen dominated New World cod fisheries throughout the 16th century. ${ }^{43}$ After 1580, when the Danish crown imposed heavy license fees on boats in Icelandic waters, numerous English West Country fishermen shifted from there to North American waters. ${ }^{44}$ Although the Portuguese catches in the 16th century were almost insignificant in the overall balance of Newfoundland fisheries, they were such that the internal market was saturated with cod. If the impact of such activity is not comparable to recent times, due mostly to the earlier use of incipient catching technologies and ships, the pattern of exploitation was already settled in the 16 th century.

The same applies to the hunt for sea lions, because of their skins, the catching of civet cats, because of the secretion of their glands, to the near-extinction of American beavers, to dress fishermen in Northern Europe or to feed the leather industry all over Europe, or the killing of whales because of their oil used to illuminate large European cities such as London. ${ }^{45}$

Portuguese documentary registers and travel literature are likewise eloquent about massive catches of mammals, particularly cetaceans and other marine species, ${ }^{46}$ undertaken since the

${ }^{43}$ As for the Newfoundland codfish catches in the first period of European contacts, see Darlene Abreu-Ferreira, "Terra Nova through the Iberian Looking Glass: The PortugueseNewfoundland Cod Fishery in the Sixteen Century," Canadian Historical Review 79, no. 1 (1998): 100-15; Peter Pope, "Early Estimates: Assessment of Catches in the Newfoundland Cod Fishery 1660-1690," in Papers presented at the conference entitled "Marine Resources and human societies in the North Atlantic since 1500," October 20-22, 1995, Memorial University of Newfoundland, St. John's, Newfoundland (St. John's, Newfoundland: The Institute of Social and Economic Research, Memorial University of Newfoundland, 1997).

${ }^{44}$ Ralph Greenlee Lounsbury, The British Fishery at Newfoundland, 1634-1763 (New Haven: Yale University Press, 1934); Olaf U. Janzen, "The Logic of English Saltcod: An Historiographical Revision" (Paper presented at the 6th 6IMEHA Conference, Ghent, Belgium, July 2012).

${ }^{45}$ David Haines, "Lighting up the World? Empires and Islanders in the Pacific Whaling Industry, 1790-1860,” in Maritime History as Global History, ed. Fusaro and Polónia, 159-75.

${ }^{46}$ See, for the Portuguese case, Cristina Brito, Os mamíferos marinhos nas viagens marítimas pelo Atlântico entre os séculos XV e XVIII: a evolução da ciência do conhecimento (Lisboa: UNL-FCDH, 2009); Brito, “The Historical Ecology and Economy of the Ambergris 
very first moment of contact, in Africa or on the Brazilian coasts. Those behaviors, driven mostly by economic causes, implied significant costs for environmental and ecological steadiness.

Ecological and environmental equilibriums were unbalanced, not in a long-term process, but in a short and invasive process of transformation and depletion. The exploitation of indigenous natural resources on the one hand, and the introduction of European animals, seeds, plants and diseases, on the other, were both sides of the same coin. ${ }^{47}$

Although technological limitations prevented, during the period under analysis, a radical exhaustion of resources, they foretold economic behavior and market logics according to which profit justified ecosystem destruction. The new explorers took the inexhaustibility and everlasting existence of species for granted, or did not even consider it. Just like indigenous people did not have a legal status in the eyes of most of the European colonizers, autochthone ecosystems did not have any kind of regulation (unlike in Europe) designed to prevent their exhaustion and extinction, at least until the 18th century. Botanic species were totally destroyed in the Atlantic archipelagos which had, until then, been inhabited, as in Madeira, the Azores and the Canary Islands; in the same way the inhabitants of the Canary Islands disappeared together with their ecosystems.

All of these phenomena had effects upon the micro or medium territorial or maritime scale; they were nevertheless driven by external, sometimes global colonial policies.

Apart from that, the historian also faces the question of global ecological transfers between continents, across oceans. Crosby stresses the symbiotic process originated from a largescale exchange of animals, plants, seeds, but also bacteria, virus-

in the Atlantic" (Paper presented at the 6th IMEHA Conference, Ghent, Belgium, July 2012); Brito, "The Environmental History of Cetaceans in Portugal: Ten Centuries of Whale and Dolphin Records,” PLosONE 6, no. 9 (September 2011). Available at http://journals.plos.org /plosone/article?id=10.1371/journal.pone.0023951; Brito and Andreia Costa, "Medieval and Early Modern Whaling in Portugal," Anthrozoos: A Multidisciplinary Journal of The Interactions of People \& Animals 24, no. 3 (September 2011): 287-300.

${ }^{47}$ Alfred Crosby, "Ecological Imperialism: The Overseas Migration of Western Europeans as a Biological Penomenon,” in The Ends of the Earth, 114-15. 
es and diseases. ${ }^{48}$ This is usually analyzed as a unilateral process. Conversely, one could argue, coffee, cacao, tobacco, tea, potatoes, tomatoes, rice changed, in the medium run, European habits and consumption patterns. Some had direct impact on European industries, like the provisioning of cotton, the use of dyes like indigo, brazil-wood, cochineal, pastel or heath, in the textile industry. While some of those products remained attached to elite circles, others contributed to a medium-term process of "democratization" of consumption patterns, as happened with sugar and spices, and to the transformation of land exploitation and agricultural uses of the soil, as with maize corn or potato plantations. Europe was not untouched by this massive process of transferences, even if an overall assessment of those impacts remains to be done.

\section{ENVIRONMENTAL HISTORY AS GLOBAL HISTORY}

According to the approach previously presented, European imperial agents caused the destruction of tropical forests and the replacement of indigenous uses of the soil by an intensive agrarian exploitation system. Aggressive behavior towards preexistent environments can be witnessed, as well as the depletion of natural resources; the extinction of vegetal and animal species, or the destruction of ecosystems. Landscapes are changed drastically.

Those trends have been proven empirically and are, thus, unquestionable. However, this is a reductionist way of putting the case. It stresses the connections between power (the colonial power) and nature, but usually overlooks the fact that this interaction itself occurs in an environment created by previous cultural systems. As such Australian systems differed from those in Asia, Africa and America, and even quite different ones existed in the same continent. Some of them were the outcomes of previous imperial conquests, like the Mayas' in America, imperial

${ }^{48}$ Noble David Cook, Born To Die: Disease and the New World Conquest, 1492-1650 (Cambridge: Cambridge University Press, 1998); William M. Denevan, The Native Population of the Americas in 1492, 2nd ed. (Madison: University of Wisconsin Press, 1992). 
China, or the advance of a Muslim political and economic dominium in India or on the East Coast of Africa.

The traditional perspective, focusing on "ecological imperialism," not only frequently disregards those cultural frameworks, it also fails to consider the way ecosystems react to the invaders and become themselves builders of different environments. In fact, the cultural patterns operating in colonial spaces were not only or not even predominantly the European ones. The perspective of analysis which informs the focus on "ecological imperialism," even if motivated by the analysis of the impact of European colonialism upon indigenous cultures and environments, projects after all a Eurocentric, or else Western centric model of analysis, according to which the local agents, the colonized, are usually excluded from the analysis of the dynamics of colonial processes, with the global interpretations centering almost exclusively on the deterministic performance of Europeans. ${ }^{49}$

In fact, the way Africa, America or Australia, as well as the African, Amerindians or Australian Aborigines assimilated and reacted to European inputs has been insufficiently studied. The same can be said about the differences between them. If Europeans were one among many in the Indian Ocean world, performing on a global stage already set when they arrived, ${ }^{50}$ their footprint in Africa and America was certainly more impressive. On the other hand, the level of influence and the assimilation processes varied according to the European agents and the preexisting model of colonization, as well as according to the different degrees of imposition or assimilation behavior.

In the Early Modern Age, the increase of human population and the expansion of human settlements and sedentary cultivation in the non-European worlds occurred, and facing the Euro-

${ }^{49}$ There are some exceptions. See, for instance, Timothy C. Weiskel, "Toward an Archaeology of Colonialism: Elements in the Ecological Transformation of the Ivory Coast," in The Ends of the Earth, ed. Worster, 141-54. Elinor G. K. Melville, A Plague of Sheep: Environmental Consequences of the Conquest of Mexico (Cambridge: Cambridge University Press, 1994). It could also be mentioned as an approach by which indigenous agency in environmental change is acknowledged.

${ }^{50}$ Sanjay Subrahmanyan, ed., Merchants, Markets and the State in Early Modern India (Delhi; Oxford: Oxford University Press, 1990); K. N. Chaudhuri, The Trading World of Asia and the English East India Company 1660-1760 (Cambridge: Cambridge University Press, 1978). 
pean pressure, at the expense of forests, woodlands, wetlands, and savannas. Even so, one cannot compare without criticism the effects of that trend in North America or in Brazil, for instance. A quite different model of colonization; a quite different way of state empire building; a quite different degree of regulation and a different regime of property were responsible for diverse ecological and human impacts.

Considering, on the other hand, the mutual interferences between Nature and Culture, and assuming that the cultural systems of colonizers and indigenous people are autonomous but mutually interdependent, one should be aware of the need for a shift in the historical analysis. This shift is already on its way regarding the history of empires. Would it be possible to initiate it for environmental history? And would this shift be able also to project new directions in Global History and World History?

In fact, at present days classic studies on empire building are in fact under revision. New generations of scholars tend to inscribe colonial studies in a more trans-national, trans-cultural and trans-imperial perspective of analysis. The outputs of the so -called post-colonial studies, developed since the 1980s; the more recent perspectives centered on a connected history of the colonial empires, ${ }^{51}$ or the agenda of a highly prolific world history or global history ${ }^{2}$ have been contributing to a revision of those Eurocentric and westerly oriented interpretations of colonial phenomena, diluting national state or imperial policies in a much more broad complex and holistic approach. ${ }^{53}$ Recent historiographical contributions have been set in motion, ${ }^{54}$ and the

${ }^{51}$ Sanjay Subrahmanyam, "Holding the World in Balance: The Connected Histories of the Iberian Overseas Empires, 1500-1640," American Historical Review 112, no. 5 (December 2007): 1359-85.

${ }^{52}$ See the abundant publications e.g. in the Journal of World History (Haway Univerity Press); the Journal of Global History (Cambridge); Itinerario. International Journal on the History of European Expansion and Global Interaction (Leiden Institute of Area Studies (LIAS) and (FEEGI); the Asian Review of World Histories (AAWH).

${ }^{53}$ See, for instance, and for the Indian Ocean, James C. Boyajian, Portuguese Trade in Asia under the Habsburgs, 1580-1640 (Baltimore: The Johns Hopkins University Press, 1993).

${ }^{54}$ A. Polónia, The Power of the Commoners. Individuals vs. State in the Portuguese Overseas Expansion. [Forthcoming]; A. Polónia and A. Barros, "Articulações Portugal / Brasil. Redes informais na construção do sistema Atlântico (séculos XVI - XVIII),” in Politi cas e Estratégias Administrativas no Mundo Atlântico (Recife: Editora Universitária/UFPE, 2012), 19-48. 
organization of scientific panels and conferences on the subject brought together specialists driven by the same desire: the scrutiny of informal and self-organized ways of empire building, in which cooperation is paramount. ${ }^{55}$

The first line of these new directions should be an actual awareness that interaction, adaptation and assimilation processes were never unidirectional. In this sense, there is a significant range of tropical and Asian products which should be particularly emphasized by their massive and structural effects on the food regime of Europe and Africa: the corn maize and the potatoes became the basis of European food regimes and prevented massive famines; the cassava, or the mandioca, coming from America, remains today the basis of the diet of a great deal of the African population. ${ }^{56}$ Rice, an eastern, Chinese product, became a transatlantic plantation product, and one of the main bases of the colonial economy of the British Empire. Tea became an essential product and cultural symbol. The fact that the increasing taxes on tea were one factors contributing to the uprising of the British settlers in America against the crown is evidence of the way those transfers were effective and assimilated by the European, becoming central elements on their diet and daily habits. In some ways, colonized ecosystems colonized the Europeans and affected their daily habits, as did all kinds of spices, sugar, coffee or tobacco arriving in Europe. This is thus a reciprocal dynamic, which the concepts of "green imperialism" or "ecological imperialism" are not able to comprehend satisfactorily. . .

${ }^{55}$ See, e.g. the panel sessions: The Power of the Commoners. Informal Agent-based Networks as Source of Power in the First Global Age, coord. Amélia Polónia, held at the American Social Science History Conference 2010 (Chicago, November 2010); Beyond Empires: Self Organizing Cross Imperial Networks vs Institutional Empires, 1500-1800, coord. Amélia Polónia and Cátia Antunes, held at the European Social Science History Conference 2012 (Glasgow, Scotland, April 2012) or the Conference Cooperation under the Premise of Imperialism, coord. Tanja Bührer, Flavio Eichmann, Stig Förster, Benedikt Stuchtey, Dierk Walte (Held at the University of Bern, Switzerland, June 2013. Organizers: German Historical Institute, London; Hamburger Institut für Sozialforschung; University of Bern).

${ }^{56}$ For a more detailed analysis of the travel of seeds and plants, see José Eduardo Mendes Ferrão, A aventura das plantas e os descobrimentos (Lisboa: Instituto de Investigação Científica Tropical, 1992). 


\section{EPILOGUE}

Studies pursued according to this understanding will probably differentiate World History and Global History and will in all likelihood prove the importance of local and regional studies in this interactive relation between the local, the regional, the inter-regional and the global. Research programs at local and regional levels will have to be effected, to obtain answers with a global and worldwide meaning. The Indian Ocean will have a privileged position in these historiographical queries, as it benefited from long-term processes of transference and circulation of products, people, ideas, technologies and cultures.

The possible input of environmental history of the period under scrutiny, if any, is two-fold: in one way, it might contribute to the comprehension of human dynamics and human behaviors responsible for stressful environmental changes felt at a global level, and their long term consequences; in another way, it might help to understand the availability and the limits of ecosystems to survive and to adapt to changing environmental frameworks.

The period under scrutiny (1500-180o); the process under analysis (the encounter/confrontation between different cultures and between different ecosystems) might contain accurate contributions to the currently debate on environmental changes and environmental (un)sustainability and its implications at a worldwide level, and at a global scale.

This paper calls thus for future contributions to a better understanding of the ecosystems' ability to survive by adapting to changing environmental frameworks. The analysis of longterm environmental dynamics has the potential of contributing to an identification of both the costs and the mechanisms which overtook, in the past, points of environmental unsustainability. The paper intends furthermore to call for the discussion of issues of (under-) development and the understanding of the great divergence (convergence nowadays?) between the East and the West. It introduces into this debate, apart from questions involving Nature, compelling issues of Culture. As Nature and Culture are two main elements of the same equation, History cannot 
perform alone the endeavor of understanding the complex process involved in environmental change. It endorses the belief that "The enormity of ecological change strongly suggests that history and ecology, at least in modern times, must take one another into account . . . Ecology that neglects the complexity of social forces and dynamics of historical change is equally limited. Both history and ecology . . . need to integrate with one another." 57

Incorporating human decision-making and cultural patterns in an equation designed to explain the evolution of collective behavior allows researchers (and not only historians) to rethink issues of sustainable development at a par with Economics. Kenneth Pomeranz's work sets the tone in this debate. ${ }^{58}$ As important as how, in the past, resources availability and management interfered with divergent development trends between the East and the West ("The great divergence"), is the debate on how the apparent convergence performed e.g. by India, China and Brazil nowadays will impact on environment and natural resources scarcity and exhaustibility. This is a main concern of UN's Future Earth program, a ten-year international research initiative that intends to develop the knowledge for responding to the risks of global environmental change, supporting transformation towards global sustainability. Aiming at proving sustainable options and solutions in the wake of Rio+20, Future Earth ${ }^{59}$ intends to massively mobilize scientists to these challenges. This paper hopes, within the scope of an on-going larger debate, ${ }^{60}$ to contribute to this appeal.

${ }^{57}$ J. McNeill, The Historiography of Environmental History in EOLSS (Oxford: Eolss Publishers, 2010) [http://www.eolss.net]

${ }^{58}$ Kenneth Pomeranz, The Great Divergence : China, Europe, and the Making of the Modern World Economy (Princeton: Princeton University Press, 2000).

${ }^{59}$ http://www.icsu.org/future-earth.

${ }^{60}$ See the conference panel, coord. Amélia Polónia, Circulating Natures in the First Global Age. Ecological Imperialism versus Ecological Adaptation, in World Congress of Environmental History 2014, Guimarães (Portugal), July 8-12, 2014. Available at http://www. ecum.uminho.pt/uploads/eventos/EV_9098/20140707454722830000.pdf, p. 36. [Accessed at January, 9, 2015] 